\title{
Strategi Humas Dalam Promosi Penerimaan Peserta Didik di MTs Ma'Arif NU Kemiri Purworejo
}

\author{
Isnaini' ${ }^{1}$ Evita Rohmah ${ }^{2}$ \\ 1,2 Sekolah Tinggi Agama Islam An-Nawawi Purworejo \\ E-mail: ini64308@gmail.com, evitaroo88@gmail.com
}

\begin{abstract}
Article Info
Abstract

Article History

Received: 2021-08-27

Revised: 2021-09-25

Published: 2021-10-23

Public relations is a two-way communication between the organization and the public reciprocally to achieve common goals. The existence of competition between educational institutions in finding educational customers, a marketing strategy is needed. MTs Ma'arif NU Kemiri Purworejo is an educational institution that has experienced an increase in the number of students in the last two years. The author

Keywords:

Strategy;

Public Relations;

Promotion. will analyze the public relations strategy applied in the promotion of student admission at MTs Ma'arif NU Kemiri Purworejo. The method used in this research is descriptive qualitative. Data collection techniques in this study by means of interview, observation and document review. The data analysis used in this research is a qualitative method with a deductive frame of mind. After analyzing the public relations strategy in the promotion of student admission that was implemented in MTs Ma'arif NU Kemiri Purworejo, it was shown that the public relations strategy in promoting student acceptance at MTs Ma'arif NU Kemiri Purworejo has generally been carried out well even though there are some obtacles but it has been several attempts were made to overcome these obstacles.
\end{abstract}

\begin{tabular}{l}
\hline Artikel Info \\
\hline Sejarah Artikel \\
Diterima: 2021-08-27 \\
Direvisi: 2021-09-25 \\
Dipublikasi: 2021-10-23
\end{tabular}

Kata kunci:

Strategi;

Humas;

Promosi.

\begin{abstract}
Abstrak
Hubungan masyarakat adalah komunikasi dua arah antara organisasi dengan publik secara timbal balik untuk mencapai tujuan bersama. Adanya persaingan antar lembaga pendidikan dalam mencari pelanggan pendidikan maka diperlukan strategi pemasaran. MTs Ma'arif NU Kemiri Purworejo merupakan lembaga pendidikan yang mengalami peningkatan jumlah peserta didik dalam dua tahun terakhir. Penulis akan menganalisis strategi humas yang diterapkan dalam promosi penerimaan peserta didik di MTs Ma'arif NU Kemiri Purworejo. Metode yang digunakan dalam penelitian ini adalah deskriptif kualitatif. Teknik pengumpulan data dalam penelitian ini dengan cara wawancara, observasi dan telaah dokumen. Analisis data yang digunakan dalam penelitian ini adalah metode kualitatif dengan kerangka berfikir secara deduktif. Setelah melakukan analisis terhadap strategi humas dalam promosi penerimaan peserta didik yang diterapkan di MTs Ma'arif NU Kemiri Purworejo menunjukan bahwa strategi humas dalam promosi penerimaan peserta didik di MTs Ma'arif NU Kemiri Purworejo secara umum telah terlaksana dengan baik meskipun terdapat beberapa kendala tetapi telah dilakukan beberapa upaya untuk mengatasi kendala tersebut.
\end{abstract}

\section{PENDAHULUAN}

Sekolah sebagai lembaga formal yang tidak pernah lepas dari pengaruh lingkungan dan masyarakat, pihak sekolah sudah sepantasnya mulai memahami bahwa sekolah tidak bisa berjalan tanpa adanya dukungan dan kepercayaan dari masyarakat. Sistem komunikasi yang baik akan menjadi penghubung antara sekolah dengan masyarakat. Peran humas sangat dibutuhkan untuk membentuk komunikasi yang baik dengan masyarakat sehingga citra baik lembaga akan ikut terbentuk. Pelaksanaan peran humas tersebut diperlukan strategi yang matang sehingga tidak hanya baik secara teori tapi dalam pelaksanaannya pun bisa maksimal.

Tugas lembaga pendidikan tidak cukup sampai pada hubungan yang baik serta pelayanan yang baik akan tetapi bagaimana hubungan lembaga dengan masyarakat tersebut tidak meregang, artinya kepercayaan yang telah diberikan masyarakat terhadap lembaga tidak terkikis sehingga diharapkan mampu menciptakan dan mengembangkan pandangan masyarakat terhadap perkembangan sebuah lembaga pendidikan. Lembaga pendidikan baik Negeri maupun Swasta beserta dengan kualitas masingmasing bersaing dalam pasaran pendidikan dalam menawarkan jasa pendidikan, tanpa 
adanya manajemen yang baik dari lembaga pendidikan tersebut akan sulit untuk mempertahankan eksistensinya dalam dunia pendidikan, untuk itu dibutuhkan strategi yang matang dalam penyelenggaraanya, Strategi menurut istilah merupakan rencana yang mengandung cara komprehensif dan integratif yang dapat dijadikan pegangan untuk bekerja, berjuang dan berbuat guna memenangkan kompetisi Rosadi Ruslan mengutip pendapat Ahmad S. Adnanputra, M. A., M.S., seorang Pakar Humas dalam naskah workshop yang berjudul $P R$ Strategy, mengatakan

Arti strategi adalah bagian terpadu dari suatu rencana (plan), sedangkan rencana merupakan produk dari suatu perencanaan (planning), yang pada akhirnya perencanaan adalah salah satu fungsi dasar manajemen. Strategi manajemen humas adalah alternatif optimal yang dipilih untuk ditempuh guna mencapai tujuan public relations dalam kerangka suatu rencana public relations (Ruslan,2007:113134).

Berdasarkan pengertian tersebut dapat dipahami bahwa strategi hubungan masyarakat pada dasarnya adalah sebuah perencanaan yang bersifat besar, luas dan terintegrasi serta berorientasi masa depan sehingga sangat berpengaruh bagi kemajuan organisasi dengan mempertimbangkan faktor-faktor eksternal dan internal untuk meraih tujuan lembaga pendidikan, Scott M. Cutlip and Allen H. Centre, dalam bukunya Effective Public Relations menjelaskan bahwa

Public Relations adalah fungsi manajemen yang menilai sikap publik, mengidentifikasi kebijakan dan tata cara organisasi demi kepentingan publiknya, serta merencanakan suatu program kegiatan dan komunikasi untuk memperoleh pengertian dan dukungan publiknya.

Humas dapat diartikan sebagai suatu kegiatan usaha yang berencana yang menyangkut iktikad baik, rasa simpati, saling mengerti untuk memperoleh pengakuan, penerimaan dan dukungan masyarakat melalui komunikasi dan sarana lain (media massa) untuk mencapai kemanfaatan dan kesepakatan bersama (Mulyono,2009:201), Humas dalam menjaga hubungan antara organisasi atau lembaga dengan publiknya dalam $\mathrm{Al}$ Quran juga dijelaskan untuk menjaga hubungan baik dengan sesama manusia (publik), terdapat pada surat AL-Maidah ayat 2.

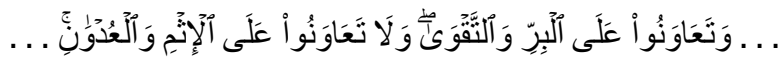

Artinya: “ . . dan tolong-menolonglah kamu dalam (mengerjakan) kebaikan dan taqwa, dan jangan tolong menolong dalam berbuat dosa dan permusuhan.(Q.S Al-Maidah ayat 2)

Sekolah atau lembaga yang mengedepankan budi pekerti yang baik untuk menggandeng masyarakat tentunya masyarakat akan dengan suka rela memberikan apa yang menjadi kebutuhan sekolah dari masyarakat. Bentuk kerjasama yang terjalin akan berhasil apabila didasari oleh budi pekerti yang baik. Salah satu langkah dalam membentuk budi pekerti yang baik adalah dengan menjalin komunikasi antara lembaga dengan publik, sehingga dapat menipiskan kemungkinan terjadi kesenjangan akibat kurangnya komunikasi antara lembaga dengan publik. Hubungan kerja sama sekolah dan masyarakat menurut M. Ngalim (1995:190) dapat digolongkan menjadi tiga jenis hubungan, yaitu (1) hubungan edukatif, (2) hubungan kultural, (3) hubungan institusional.

Suryosubroto (2012:26-31) membagi kegiatan humas menjadi dua bagian, yaitu kegiatan eksternal dan kegiatan internal. Kegiatan eksternal terdiri dari kegiatan secara langsung (tatap muka) dan kegiatan secara tidak langsung, sama halnya dengan kegiatan eksternal kegiatan internal pun terdiri dari kegiatan secara langsung dan kegiatan secara tidak langsung. Sedangkan untuk media humas Soehardiman Yuwono menggolongkan media humas ke dalam tiga jenis yaitu, media audio (indra pendengaran), media visual (indra penglihatan), dan media audiovisual (indra pendengaran dan penglihatan), Mamo dan Triyo priyanto (2008:99) mengatakan Tahapan Strategi Hubungan Masyarakat (Humas) secara sistematis sebagai berikut:

1. Penjajagan kebutuhan.

2. Perencanaan kegiatan.

3. Pelaksanaan kegiatan (implementasi).

4. Pemantauan (monitoring).

5. Evaluasi program.

Strategi Hubungan Masyarakat (Humas) dalam Promosi adalah aktivitas-aktivitas atau peristiwa-peristiwa yang dirancang untuk menjamin dukungan atau pengakuan tentang diri seseorang, produk, lembaga atau organisasi (Frazie moore,2005:5). Dalam dunia pendidikan juga mengenal kata promosi, promosi pendidikan adalah kegiatan memperkenalkan, menawarkan mutu, visi dan misi serta tujuan sebuah sekolah 
kepada masyarakat sebagai konsumennya. Dengan tujuan menarik minat masyarakat berpartisipasi aktif dalam sekolah tersebut. Tim Dosen Administrasi Pendidikan UPI (2011:337) mengutip pendapat John R Siber yang menyatakan bahwa etika marketing dalam dunia pendidikan adalah menawarkan mutu layanan intelektual dan pembentukan watak secara menyeluruh. Hal ini disebabkan pendidikan lebih bersifat kompleks yang dilaksanakan dengan penuh tanggungjawab, dan hasil pendidikannya mengacu ke depan, membina kehidupan warga negara dan generasi penerus bangsa di kemudian hari, Menurut Motik yang dikutip oleh Zulkarnaini Nasution (2010:4) sebuah lembaga pendidikan dalam kaitan penerimaan peserta didik, ada enam tahapan yang harus dilakukan dalam pemasaran pendidikan, yaitu:

1. Asumsi lembaga pendidikan tidak memerlukan pemasaran.

2. Pemasaran merupakan promosi.

3. Pemasaran merupakan segmentasi dari penelitian pemasaran.

4. Pemasaran merupakan penetapan posisi.

5. Pemasaran merupakan perencanaan strategi.

6. Pemasaran merupakan manajemen penerimaan siswa atau mahasiswa.

Persaingan dalam mendapatkan kepercayaan dari masyarakat tentunya tidaklah mudah, diperlukan strategi humas yang baik untuk membentuk komunikasi yang baik guna membentuk citra lembaga dan mendapatkan kepercayaan masyarakat, keberhasilan strategi humas yang tercapai salah satunya dapat dilihat dari peningkatan jumlah peserta didik dalam setiap tahunnya. MTs Ma'arif NU Kemiri merupakan salah satu lembaga pendidikan swasta di Kabupaten Purworejo yang mengalami peningkatan jumlah peserta didik, dapat dilihat berdasarkan telaah dokumen MTs Ma'arif NU Kemiri Purworejo pada tahun ajaran 2019/2020 terjadi peningkatan jumlah peserta didik sebanyak 34 siswa dan pada tahun ajaran 2020/2021 terjadi peningkatan jumlah peserta didik sebanyak 51 siswa (Arsip MTs Ma'arif NU Kemiri Purworejo, 2020/2021).

Berdasarkan uraian tersebut, maka menarik untuk dijadikan fokus dalam penelitian dari peningkatan jumlah peserta didik dalam dua tahun terakhir di MTs Ma'arif NU Kemiri Purworejo, seperti apa strategi humas yang diterapkan di MTs Ma'arif NU Kemiri Purworejo dalam promosi penerimaan peserta didik, dan kendala apa saja yang dihadapi MTs Ma'arif NU
Kemiri Purworejo dalam promosi penerimaan peserta didik serta upaya apa yang dilakukan untuk mengatasi kendala yang ada dalam promosi penerimaan peserta didik di MTs Ma'arif NU Kemiri Purworejo.

\section{METODE PENELITIAN}

Penelitian ini merupakan jenis penelitian lapangan atau field research. Penelitian ini bersifat deskriptif analitik, yaitu dengan mendeskripsikan tentang strategi humas dalam promosi penerimaan peserta didik kemudian dianalisis dengan teori-teori strategi humas dan promosi yang telah dikemukakan oleh para pakar. Jenis data yang digunakan terdiri dari data primer dan sekunder. Adapun Sumber data yang digunakan juga ada dua, meliputi sumber data primer berupa Kepala Sekolah dan Waka bagian Humas, serta sumber data sekunder berupa buku-buku, artikel, majalah, jurnal, data-data yang diperoleh dari internet, dokumen-dokumen yang ada hubungannya dengan penelitian yang akan dikaji (Soekanto,1986: 52), adapun metode pengumpulan data yang digunakan melalui beberapa cara, yaitu wawancara, observasi dan juga telaah dokumen. Metode analisis data yang penulis gunakan merupakan analisis data model kualitatif, dimana data yang diolah bukan berupa angka-angka, dan dianalisa dengan cara berfikir deduktif yaitu cara berfikir yang bertolak dari sebuah asumsi atau pernyataan yang bersifat umum untuk mencapai sebuah kesimpulan yang bermakna lebih khusus (Mundiri,2000:4). Penelitian ini bertujuan untuk mengetahui bagaimana strategi humas yang diterapkan dalam promosi penerimaan peserta didik di MTs Ma'arif NU Kemiri serta kendala dan upaya dalam mengatasinya.

\section{HASIL DAN PEMBAHASAN}

\section{A. Hasil Penelitian}

Promosi dengan strategi pemasaran yang dilaksanakan oleh MTs Ma'arif NU tidak dilaksanakan oleh bagian humas secara khusus namun semua warga sekolah turut berkontribusi pada pelaksanaan di lapangan. Untuk meningkatkan kualitas lembaga diperlukan kerjasama semua pihak baik internal maupun eksternal termasuk keterlibatan masyarakat. Masyarakat merupakan konsumen pendidikan, untuk meningkatkan minat masyarakat serta kepercayaan masyarakat terhadap lembaga pendidikan sehingga anak-anaknya dapat menjalankan proses pembelajaran dengan baik, maka dalam hal ini 
sekolah perlu melaksanakan strategi-strategi yang tepat untuk menarik minat masyarakat dalam promosi penerimaan peserta didik.

MTs Ma'arif NU Kemiri Purworejo terdapat beberapa strategi yang dilaksanakan khususnya oleh bidang humas dengan didukung oleh bidang lain dalam manajemen pendidikan dalam melaksanakan promosi penerimaan peserta didik. Berdasarkan wawancara dengan Kepala Sekolah, strategi yang dilaksanakan dalam promosi penerimaan peserta didik, diantaranya:

1. Penyampaian informasi kepada masyarakat melalui media spanduk dan brosur yang berisi informasi sekolah profil sekolah, fasilitas pembelajaran, kegiatan ekstrakurikuler.

2. Penyampaian informasi tentang MTs Ma'arif NU Kemiri kepada masyarakat secara online melalui grup WhatApp dan Facebook.

3. Melaksanakan promosi secara langsung dengan menentukan sasaran lokasi promosi yaitu SD dan MI sederajat yang berada di sekitar lokasi MTs Ma'arif NU Kemiri.

4. Mengundang para ulama, kepala sekolah tingkat SD/ MI sederajat dan tokoh masyarakat dalam acara pelepasan siswa kelas IX.

5. Mengikutsertakan siswa-siswi dalam perlombaan mulai tingkat kecamatan.

6. Melaksanakan kegiatan outdor, seperti Perkemahan.

7. Mengadakan perlombaan tingkat SD/MI sederajat yang bertempat di MTs Ma'arif NU Kemiri (Supamo, Partisipan, 24 Desember 2020).

Kendala Humas dalam Promosi Penerimaan Peserta Didik diantaranya terjadi kelembaman struktural ( Supamo,Partisipan, 24 desember 2020), memiliki wakil kepala bagian humas dengan kredibilitas tinggi merupakan suatu keberuntungan bagi lembaga pendidikan karena humas merupakan komponen penting dalam mewujudkan visi dan misi lembaga pendidikan. Namun tidak dapat dengan berjalannya waktu jumlah usia semakin bertambah seiring penurunan kualitas kerja, maka perlunya dilaksanakan kaderisasi dengan tujuan mencetak generasi penerus yang mampu memberikan kontribusi positif bagi lembaga pendidikan.

Kurang maksimal dalam pelaksanaan promosi pada sasaran yang telah ditentukan
(Mucharor ,partisipan 20 Desember 2020). Hal tersebut bisa disebabkan karena kurang mumpuninya wakil sekolah dalam melaksanakan promosi sehingga respon dari konsumen kurang positif. Kendala selanjutnya persaingan dengan lembaga pendidikan yang lain dalam mendapatkan pelanggan pendidikan (Muharor, partisipan 20 Desember 2020). Dunia pendidikan yang semakin menjadi perhatian pemerintah seiring dengan kemajuan zaman tidak dapat dihindari usaha lembaga pendidikan untuk terus berkembang menjadi berkualitas baik dari segi intelektual maupun segi fisiknya menjadikan persaingan yang cukup ketat, bagi pelanggan pendidikan tentunya akan lebih mempertimbangkan lembaga pendidikan yang bagaimana yang akan dipercaya mampu membentuknya menjadi generasi penerus bangsa yang berkualitas.

\section{B. Pembahasan}

Lembaga pendidikan dalam meningkatkan kualitasnya tentu banyak yang harus diperhatikan, baik dari pendidik dan tenaga kependidikan, sarana dan prasarana dalam menunjang proses pendidikan, siswa siswi termasuk hubungan sekolah dengan masyarakat atau publik. Apabila semua unsur dalam bidang pendidikan dapat bekerja sama dalam melaksanakan tugasnya dengan baik tentu kualitas lembaga pendidikan akan semakin baik. Dalam melaksanakan peran dan tugasnya bagian dalam bidang pendidikan diperlukan strategi yang tepat sehingga kualitas lembaga pendidikan dan keberlangsungan proses pendidikan dapat berjalan dengan semestinya sesuai dengan tujuan yang diharapakan.

Berdasarkan hasil penelitian tentang bagian humas yang terdapat di MTs Ma'arif NU Kemiri terkait dengan strategi humas dalam promosi penerimaan peserta didik humas mampu melaksanakan peran dan tugasnya sehingga promosi penerimaan peserta didik dapat berjalan dengan baik dibuktikan dengan adanya peningkatan jumlah peserta didik dalam 2 tahun terakhir. Tentunya dengan dukungan dari warga sekolah yang lain. Hal ini dilatarbelakangi oleh terjalinnya hubungan internal yang baik, komunikasi yang baik antar semua pihak internal sekolah, guru dengan guru, guru dengan staf, staf dengan siswa dan siswa dengan guru tercipta hubungan yang baik, 
sehingga mendukung terbentuknya hubungan eksternal yang baik.

Hubungan komunikasi yang baik menjadikan MTs Ma'arif NU Kemiri semakin berkembang. Baik hubungan internal lembaga maupun hubungan eksternal seperti hubungan dengan komite sekolah, wali murid, para ulama dan masyarakat sekitar juga terjalin dengan baik, hal tersebut dapat dilihat dari dukungan masyarakat terhadap kegiatan yang dilaksanakan oleh sekolah serta kerja sama yang terjalin dengan berbagai pihak. Strategi humas dalam promosi penerimaan peserta didik di MTs Ma'arif NU Kemiri secara umum sudah terlaksana dengan baik dengan didukung oleh iklim organisasi dan tersedianya sarana dan prasarana serta dana yang memadai, dapat dilihat dengan adanya peningkatan jumlah peserta didik dalam dua tahun terakhir. Akan tetapi apabila ditelaah secara khusus tentunya terdapat kekurangan baik dari rancangan program, perencanaan strategi maupun pelaksanaan kegiatan tersebut, beberapa hal terkait kendala strategi humas dalam promosi penerimaan peserta didik di MTs Ma'arif NU Kemiri.

Berdasarkan teori yang telah dikemukakan ada beberapa kendala lain yang dihadapi Humas MTs Ma'arif NU Kemiri Purworejo, diantaranya Kelembaman struktural, kurang maksimal dalam pelaksanaan promosi pada sasaran yang telah ditentukan, serta persaingan dengan lembaga pendidikan yang lain dalam mendapatkan pelanggan pendidikan. Beberapa upaya yang dilakukan dalam mengatasi kendala tersebut diantaranya dengan melaksanakan pergantian jabatan kepemimpinan, hal tersebut tidak dilakukan secara langsung akan tetapi sebelumnya perlu persiapan membentuk generasi penerus yang diharapkan mampu memberikan kontribusi positif bagi lembaga pendidikan.

Upaya selanjutnya dengan memberikan bimbingan dan motivasi khususnya dari kepala sekolah. Kegagalan pada program sebelumnya seharusnya menjadi landasan perbaikan untuk kedepannya, dengan pengarahan dalam rapat, pelatihan dan bimbingan serta motivasi mampu membentuk membentuk kepercayaan diri sehingga dapat memaksimalkan kemampuan diri dalam melaksanakan promosi penerimaan peserta didik dengan lebih baik. Persaingan dengan lembaga pendidikan yang lain dalam mendapatkan pelanggan pendidikan. Upaya yang dilakukan dengan merencanakan strategi pemasaran yang lebih baik sehingga mampu menarik minat pelanggan pendidikan terhadap MTs Ma'arif NU Kemiri tentunya hal tersebut akan membawa pengaruh positif dalam promosi penerimaan peserta didik.

\section{SIMPULAN DAN SARAN}

\section{A. Simpulan}

Berdasarkan pada pembahasan dan hasil penelitian yang telah penulis lakukan mengenai strategi humas dalam promosi penerimaan peserta didik di MTs Ma'arif NU Kemiri Purworejo melalui kegiatan wawacanra, observasi dan telaah dokumentasi, maka dapat ditarik kesimpulan sebagai berikut:

1. Strategi humas dalam promosi penerimaan peserta didik di MTs Ma'arif NU Kemiri Purworejo secara umum telah terlaksana dengan baik, terbukti dengan adanya peningkatan jumlah peserta didik dalam dua tahun terakhir. Dengan melakukan komunikasi dan menjalin hubungan baik antara pihak internal maupun eksternal sekolah, mampu mengoptimalkan pelaksanaan promosi penerimaan peserta didik. Selain itu strategi humas yang dilaksanakan melalui media brosur, spanduk, website, grup WhatsApp juga mendukung keberhasilan promosi. Melaksanakan promosi secara langsung, menjalin hubungan kerjasama baik dengan para ulama sekitar merupakan suatu strategi promosiyang memberikan nilai positif bagi lembaga pendidikan.

2. Kendala strategi humas dalam promosi penerimaan peserta didik di MTs Ma'arif NU Kemiri diantaranya kelembaman struktural yang menumbuhkan kenyamanan dengan struktur yang telah ada, kurang maksimal dalam pelaksanaan promosi pada sasaran yang telah ditentukan, serta persaingan dalam mendapatkan pelanggan pendidikan.

3. Upaya humas untuk mengatasi kendala dalam promosi penerimaan peserta didik di MTs Ma'arif NU Kemiri, diantaranya dengan melakukan kaderisasi atau membentu generasi penerus yang mumpuni untuk meneruskan jabatan kepemimpinan. Pengarahan, pelatihan, bimbingan serta motivasi dalam membentuk karakter sehingga mampu memaksimalkan kemampuan diri. Upaya 
yang selanjutnya yaitu dengan merencanakan dan melaksanakan strategi pemasaran yang lebih baik untuk menarik minat pelanggan pendidikan.

\section{B. Saran}

Setelah melakukan penelitian dan menganalisis strategi humas dalam promosi penerimaan peserta didik di MTs Ma'arif NU Kemiri, maka penulis sekiranya memberikan saran sebagai berikut:

1. Disarankan agar terus mengembangkan strategi humas dalam promosi penerimaan peserta didik di MTs Ma'arif NU Kemiri dan humas lebih informatif serta inovatis dalam menyajikan dan menjalin hubungan baik dengan pihak internal dan eksternal.

2. Kepala sekolah dan bagian humas untuk lebih melibatkan masyarakat sekitar dalam pelaksanaan kegiatan sekolah agar komunikasi dapat terbentuk lebih baik.

3. Lebih mengoptimalkan dan memaksimalkan promosi secara langsung maupun secara tidak langsung demi keberlangsungan citra baik lembaga pendidikan.

\section{DAFTAR RUJUKAN}

Cutlip, Scott M., dkk. 2005. Effective Public Relations: Merancang dan Melaksanakan Kegiatan Kehumasan dengan Sukses. Alih Bahasa Ch. Renata V.H. Pohan. Jakarta: INDEKS Kelompok Gramedia. Edisi ke-8.

Departemen Agama RI. 2007. Al-Qur'an dan Terjemahnya. Bandung: Syigma Examedia ArkanLeema.

Departemen Pendidikan Nasional. 2008. Kamus Besar Bahasa Indonesia, Pusat Bahasa. Jakarta: PT. Gramedia Pusat Utama. Edisi ke4.

Marno dan Triyo Supriyanto. 2008. Manajemen dan Kepemimpinan Pendidikan Islami. Bandung: PT Refika Aditama.

Moore, H. Frazie. 2005. Humas : Membangun Citra dengan Komunikasi. Bandung: Remaja Rosdakarya.
Mulyono. 2009. Manajemen Administrasi dan Organisasi Pendidikan, Jogjakarta: Ar-Ruzz Media. cet ke-2.

Mundiri. 2000. Logika. Jakarta: Raja Grafindo.

Nasution, Zulkarnaini. 2010. Manajemen Humas di Lembaga Pendidikan. Malang: UMM Press.

Purwanto, M. Ngalim. 1995. Administrasi dan Supervisi Pendidikan. Bandung: Remaja Rosdakarya. cet. ke- 7.

Ruslan, Rosadi. 2007. Manajemen Public Relation dan Komunikasi. Jakarta: Raja Grafindo Persada.

Sagala, Syaiful. 2007. Manajemen Strategik dalam Peningkatan Mutu Pendidikan. Bandung: Alfabeta.

Soekanto, Soerjono. 1986. Pengantar Penelitian Hukum cet. III. Jakarta: UI Press.

Suryosubroto, B. 2012. Hubungan Sekolah dengan Masyarakat (school public relation). Jakarta: Rineka Cipta.

Tim dosen administrasi pendidikan UPI. 2011. Manajemen Pendidikan. Bandung: Alfabeta

Wawancara dengan Bapak H. Mucharor, Wakil Kepala bagian Humas MTs Ma'arif NU Kemiri Purworejo, Tanggal 20 Desember 2020 pukul 16.00 WIB.

Wawancara dengan Bapak Suparno, S. Pd, Kepala Sekolah MTs Ma'arif NU Kemiri Purworejo, Tanggal 24 Desember 2020 pukul 10.00 WIB.

Yasin, I. (2021). Problem Kultural Peningkatan Mutu Pendidikan di Indonesia: Perspektif Total Quality Management. Ainara Journal (Jurnal Penelitian Dan PKM Bidang Ilmu Pendidikan), 2(3), 239-246. https://doi.org/10.54371/ainj.v2i3.87

Yusnarti, M., \& Suryaningsih, L. (2021). Pengaruh Model Pembelajaran Role Playing Terhadap Hasil Belajar Siswa Sekolah Dasar. Ainara Journal Uurnal Penelitian Dan PKM Bidang Ilmu Pendidikan), 2(3), 253-261. https://doi.org/10.54371/ainj.v2i3.89 